\title{
Postharvest Application of Organic and Inorganic Salts for Suppression of Silver Scurf on Potato Tubers
}

\author{
Claudia Olivier, Donald E. Halseth, Eduardo S. G. Mizubuti, and Rosemary Loria, Department of Plant \\ Pathology, Cornell University, Ithaca, NY 14853-5908
}

\begin{abstract}
Olivier, C., Halseth, D. E., Mizubuti, E. S. G., and Loria, R. 1998. Postharvest application of organic and inorganic salts for suppression of silver scurf on potato tubers. Plant Dis. 82:213-217.

Seven organic and inorganic salts were tested for suppression of silver scurf, a postharvest disease of potato tubers caused by Helminthosporium solani. Potassium sorbate, calcium propionate, sodium carbonate, sodium bicarbonate, potassium carbonate, potassium bicarbonate, and ammonium bicarbonate were added to V8 agar at concentrations of 0.06-0.2 M. Radial growth of $H$. solani was significantly reduced $(P<0.05)$ by all salts at all concentrations. All salts except sodium bicarbonate and potassium bicarbonate were fungicidal at $0.2 \mathrm{M}$. Effects of postharvest salt treatments on disease severity and sporulation of $H$. solani on inoculated and naturally infected potato tubers were evaluated in separate experiments. Greenhouse-grown tubers were inoculated with $H$. solani spore suspensions $\left(2 \times 10^{5}\right.$ spores $\left./ \mathrm{ml}\right)$, incubated for 5 days, dipped into $0.2 \mathrm{M}$ solutions of each of the salts, and incubated in a moist chamber at $22-24^{\circ} \mathrm{C}$ for 6 weeks. All salt treatments prevented lesion development and sporulation of $H$. solani and differed significantly $(P<0.05)$ from the control. Postharvest applications of test compounds $(0.2 \mathrm{M})$ also significantly $(P<0.05)$ reduced disease severity and $H$. solani sporulation on naturally infected, field-grown tubers after 15 weeks of storage at $10^{\circ} \mathrm{C}$. Salt treatments did not differ in disease or pathogen suppression. These relatively nontoxic organic and inorganic salts have potential as postharvest applications for control of silver scurf.
\end{abstract}

Silver scurf, caused by the fungus Helminthosporium solani Durieu \& Montagne, is an economically important disease of potato tubers (Solanum tuberosum L.) $(17,20)$. The tan to gray lesions are contained within the tuber periderm $(5,12,17)$. Lesions are usually clustered at the stolon end of the tuber (5) and assume a silvery appearance when moist, a symptom attributed to air pockets that develop as a result of cellulolytic activity of the pathogen. Portions of the tuber periderm may eventually slough off and cause fresh weight loss during storage. Discoloration of the tuber surface and loss of pigmentation in the periderm of red skinned cultivars reduce the marketability of infected tubers $(18,20)$.

$H$. solani grows slowly in culture and is difficult to isolate from soil. Therefore, our knowledge about the epidemiology of the disease and the ecology of the pathogen is incomplete. The seed tuber is considered to be the primary source of inoculum (18). However, soilborne propagules of $\mathrm{H}$. solani are able to survive and cause infection $(10,18,23)$. H. solani colonizes senescent tissue of several crops in vitro (23), which

Corresponding author: Rosemary Loria

E-mail: r121@cornell.edu

Accepted for publication 29 October 1997.

Publication no. D-1997-1208-02R

(C) 1998 The American Phytopathological Society ability in natural soil. Tubers often become infected during the growing season, and the first symptoms of silver scurf are evident before harvest $(12,24)$. Disease severity increases greatly during long-term storage of tubers due to lesion expansion (18) and repeated cycles of sporulation and infection $(18,29)$.

Losses due to silver scurf have increased in North America and Europe since $H$. solani developed resistance to thiabendazole (TBZ) and other benzimidazole fungicides that have been used as postharvest and seed-piece treatments on potato tubers $(13,19,22)$. In the United States, TBZ is commonly applied to potato tubers before storage to control Fusarium dry rot and likely provided control of silver scurf until resistance developed. No fungicide is currently registered for control of silver scurf in the United States, and cultural control strategies are inadequate (29). Alternative fungicide treatments are needed for the

Several inorganic salts and organic, lipophilic acids and their salts, some of which are used in the food-processing industry, have antimicrobial properties and could be useful as postharvest tuber treatments for silver scurf control. Sodium carbonate, sodium bicarbonate, potassium carbonate, potassium bicarbonate, and ammonium bicarbonate have been tested for inhibition of fungal pathogens on fruits, vegetables, field crops, and ornamentals $(1,8,15,16,38)$. Sorbic and propionic acids indicates that it may have saprophytic management of silver scurf. and their salt derivatives are used as food preservatives or as additives in animal feed for suppression of bacteria or fungi $(4,30,31)$. The efficacy of these organic and inorganic salts depends on the concentration (usually between 0.2 and 3\%) and the target microorganisms $(8,27,28)$. They can be used as food additives or applied directly to the surface of fruits, vegetables, and whole plants as dusts or by misting. These treatments are generally applied in combination with a surfactant or coating polymer $(15,16,37,38)$. Postharvest applications of organic and inorganic salts reduced black root rot on carrots caused by Chalara elegans (synanamorph: Thielaviopsis basicola) when used as a dip treatment (27).

Inorganic and organic salts often have a broad spectrum of activity, even though the mechanisms by which salts inhibit microorganisms are not well understood. Therefore, we evaluated their potential for postharvest control of silver scurf.

\section{MATERIALS AND METHODS}

In vitro tests. Cultures of $H$. solani (from potato tubers grown in New York, North Dakota, and Wisconsin) were stored on glass fiber filters (Whatman, GF/A) at $-80^{\circ} \mathrm{C}$. To initiate subcultures, pieces of the filter were transferred onto clarified vegetable juice (V8) agar plates $(200 \mathrm{ml}$ of V8 juice and $5 \mathrm{~g}$ of $\mathrm{CaCO}_{3}$, filtered through two layers of cheesecloth, and $15 \mathrm{~g}$ of agar [Bacto-Agar, Difco Laboratories, Detroit, MI] in 1 liter of distilled water). Cultures were grown for 4 to 6 weeks before use. The test compounds (all salts obtained from Sigma Chemical Co., St. Louis, MO) potassium sorbate $\left(\mathrm{C}_{6} \mathrm{H}_{7} \mathrm{O}_{2} \mathrm{~K}\right)$, calcium propionate $\left(\mathrm{C}_{3} \mathrm{H}_{5} \mathrm{O}_{2} \cdot 1 / 2 \mathrm{Ca}\right)$, sodium carbonate $\left(\mathrm{Na}_{2} \mathrm{CO}_{3}\right)$, sodium bicarbonate $\left(\mathrm{NaHCO}_{3}\right)$, potassium carbonate $\left(\mathrm{K}_{2} \mathrm{CO}_{3}\right)$, potassium bicarbonate $\left(\mathrm{KHCO}_{3}\right)$, and ammonium bicarbonate $\left(\mathrm{NH}_{4} \mathrm{HCO}_{3}\right)$ were added separately to $\mathrm{V} 8$ agar at varying concentrations (0.06-2.4 M) after autoclaving, since addition of the salts before autoclaving may result in variable inhibition (28).

For experiment one, plugs $(5 \mathrm{~mm}$ diameter) of six sporulating cultures (3SS-5 [TBZ resistant], 6SS-1 [TBZ resistant], 7SS-3 [TBZ sensitive], 9SS-1 [TBZ sensitive], 19SS-3N2 [TBZ resistant], and HSND20 [TBZ resistant]) were placed on V8 agar plates, each amended with one of the test compounds $(0.06-0.24 \mathrm{M})$, or 
unamended V8 agar as a control. Plates were incubated at $23^{\circ} \mathrm{C}$ in darkness and colony diameters were measured weekly for up to 7 weeks. The experimental design was completely randomized with three replicate plates per isolate of $H$. solani per treatment. The experiment was performed twice with similar results.

In a second experiment, potassium sorbate, calcium propionate, sodium carbonate, sodium bicarbonate, potassium carbonate, potassium bicarbonate, and ammonium bicarbonate were tested at concentrations of $0.1 \mathrm{M}(0.8-1.3 \%)$ and $0.2 \mathrm{M}$ (1.67-2.67\%) against four isolates of $H$. solani (1SS-1 [TBZ sensitive], 3SS-2 [TBZ resistant], HSND23 [TBZ resistant], and HSWS04 [TBZ sensitive]). The experiment was conducted as described above and was performed twice with similar results. The experimental design was completely randomized with three replicate plates per isolate per treatment. Data for both experiments were analyzed using ANOVA for factorial treatment design including three factors (salt, concentration, and isolates).

Mycelial plugs of $H$. solani that did not grow after 5 to 7 weeks of incubation on salt-amended V8 agar were transferred to unamended V8 agar and incubated at $23^{\circ} \mathrm{C}$ in the dark for 4 weeks to evaluate fungicidal activity. Treatments in which hyphal growth did not occur were considered fungicidal.

Because some of the salts affected the $\mathrm{pH}$ of $\mathrm{V} 8$ agar, we tested the effect of $\mathrm{pH}$ on radial growth of $H$. solani. Clarified V8 agar was adjusted with citric acid, $\mathrm{HCl}$, $\mathrm{NaOH}$, or $\mathrm{KOH}$ to $25 \mathrm{pH}$ values ranging from 3.5 to 13.5. Mycelial plugs of three isolates of $H$. solani (3SS-5, 6SS-1, and HSND23) were placed onto petri plates containing these media, incubated at $23^{\circ} \mathrm{C}$ in the dark for 4 weeks, and radial growth was measured. The experimental design was completely randomized with three replicate plates per isolate of $H$. solani per treatment. The experiment was performed twice with similar results. Data were analyzed by regression analysis using a quadratic model.

Postharvest treatments of inoculated tubers. Pathogen-free potato tubers (cvs.
Chippewa, Katahdin, and Superior) were produced in sterile peat/vermiculite mix in the greenhouse, harvested at physiological maturity, and stored at $5^{\circ} \mathrm{C}$ for up to 8 weeks. Tubers (35-55 $\mathrm{mm}$ diameter) were inoculated with spore suspensions of $H$. solani $\left(2 \times 10^{5}\right.$ spores per $\left.\mathrm{ml}\right)$ by spraying until runoff, using a Preval spray gun (Precision Valve Corporation, Yonkers, NY). Tubers were incubated in moist chambers at room temperature $\left(22-24^{\circ} \mathrm{C}\right)$ for 5 to 10 days to permit infection, and then were placed in 0.1 or $0.2 \mathrm{M}$ salt solutions or distilled water for $10 \mathrm{~min}$. Disease severity and sporulation were assessed 6 weeks after inoculation. Lesion development (percent surface area with silver scurf lesions) was estimated visually. Sporulation on the tuber periderm was measured by removing 10 periderm disks $(6 \mathrm{~mm}$ diameter) from each tuber, using a cork borer and scalpel. All disks from one tuber were placed into an Eppendorf tube $(2 \mathrm{ml})$ and vortexed in distilled water $(1 \mathrm{ml})$ to dislodge spores. The suspension was centrifuged at $5,000 \times g$ for $10 \mathrm{~min}$, tuber disks were removed, and the volume was reduced to $200 \mu \mathrm{l}$. Spores were counted using a hemacytometer. Spore counts were repeated four times for each tuber. This experiment was performed three times. Data were subjected to ANOVA, and treatment means were compared by multiple comparisons with the best (most efficacious) treatment.

Postharvest treatments of naturally infected tubers. Potatoes (cv. Katahdin) were grown in Freeville, NY, in 1995 and harvested when physiologically mature. Tubers were washed, sorted for size uniformity, and randomly assigned in groups of 80 to treatments immediately after harvest. After air drying for 30-60 min, tubers were dipped into $0.2 \mathrm{M}$ solutions of the test compounds potassium sorbate, calcium propionate, sodium carbonate, sodium bicarbonate, potassium carbonate, potassium bicarbonate, ammonium bicarbonate, or water for $2 \mathrm{~min}$. Treated tubers were placed into mesh bags, air-dried for 30 min, and stored at $10^{\circ} \mathrm{C}$ at $\mathrm{RH}>90 \%$. After 15 weeks, all tubers were rated visually for silver scurf lesions and 10 tubers were randomly selected from each treatment for sporulation studies. Data (transformed to the arcsine of the square root of lesion area) were analyzed using ANOVA, and treatment means were compared by multiple comparisons with the best (smallest lesion area).

To evaluate sporulation, tubers were incubated in a moist chamber at $22-24^{\circ} \mathrm{C}$ for 3 weeks. Ten 8-mm-diameter plugs were removed from each tuber and spore counting was performed as described previously. Data were analyzed using ANOVA, and treatment means were compared by multiple comparisons with the best (least sporulation).

Homogeneity of variances of repeated experiments was tested with the Hartley F Max test, and data were pooled when possible. All statistical analyses were performed with SAS (SAS Institute, Cary, NC). Snedecor and Cochran (33) was used as primary reference for the statistical analyses.

\section{RESULTS}

In vitro studies. Treatments and concentrations of salts had significant effects on the radial growth of $H$. solani. In experiment one, sodium and potassium bicarbonate were generally less suppressive than all other salt treatments. Sodium and potassium carbonate were more effective at $0.08-0.12 \mathrm{M}(1 \%)$ than were the respective bicarbonate salts. All salts, except potassium bicarbonate, completely inhibited growth of $H$. solani at concentrations of $\geq 0.15-0.24 \mathrm{M}(2 \%)$. Isolates of $H$. solani differed in their response to sodium bicarbonate and potassium bicarbonate at concentrations below $0.15 \mathrm{M}$ (data not shown). In the second experiment, both organic salts as well as potassium carbonate and ammonium bicarbonate at $0.1 \mathrm{M}$ (0.8-1.3\%) and $0.2 \mathrm{M}(1.67-2.67 \%)$ completely inhibited growth of $H$. solani. Sodium bicarbonate and potassium bicarbonate were the least inhibitory salts (Table 1), and isolates differed in their response to these salts $(P<0.05)$. All treatments differed significantly from the control $(P<$ 0.05 ). After 7 weeks of incubation, none of the cultures treated with $0.2 \mathrm{M}$ solutions of organic salts, carbonate salts, or ammonium bicarbonate was viable. In contrast,

Table 1. Radial growth inhibition of four isolates of Helminthosporium solani (mean of three replicates per isolate) by seven salts in vitro ${ }^{\mathrm{x}}$

\begin{tabular}{lcccccccc}
\hline Isolate & Concentration & $\mathbf{C}_{\mathbf{6}} \mathbf{H}_{\mathbf{7}} \mathbf{O}_{\mathbf{2}} \mathbf{K}$ & $\mathbf{C}_{\mathbf{3}} \mathbf{H}_{\mathbf{5}} \mathbf{O}_{\mathbf{2}} \cdot \mathbf{1} / \mathbf{2} \mathbf{C a}$ & $\mathbf{N a}_{\mathbf{2}} \mathbf{C O}_{\mathbf{3}}$ & $\mathbf{N a H C O}_{\mathbf{3}}^{\mathbf{y}, \mathbf{z}}$ & $\mathbf{K}_{\mathbf{2}} \mathbf{C O}_{\mathbf{3}}$ & $\mathbf{K H C O}_{\mathbf{3}}^{\mathbf{y}, \mathbf{z}}$ & $\mathbf{N H}_{\mathbf{4}} \mathbf{H C O} \mathbf{O}_{\mathbf{3}}$ \\
\hline 1SS-1 & $0.1 \mathrm{M}$ & 100 & 100 & 100 & $69( \pm 2.0) \mathrm{c}$ & 100 & $57( \pm 4.2) \mathrm{b}$ & 100 \\
3SS-2 & $0.1 \mathrm{M}$ & 100 & 100 & 100 & $79( \pm 2.0) \mathrm{a}$ & 100 & $72( \pm 4.0) \mathrm{a}$ & 100 \\
HSND23 & $0.1 \mathrm{M}$ & 100 & 100 & 100 & $72( \pm 4.0) \mathrm{b}$ & 100 & $73( \pm 3.0) \mathrm{a}$ & 100 \\
HSWS04 & $0.1 \mathrm{M}$ & 100 & 100 & 100 & $64( \pm 1.9) \mathrm{a}$ & 100 & $49( \pm 7.0) \mathrm{c}$ & 100 \\
1SS-1 & $0.2 \mathrm{M}$ & 100 & 100 & 100 & $84( \pm 1.0) \mathrm{ab}$ & 100 & $79( \pm 1.7) \mathrm{bc}$ & 100 \\
3SS-2 & $0.2 \mathrm{M}$ & 100 & 100 & 100 & $85( \pm 1.9) \mathrm{a}$ & 100 & $87( \pm 1.8) \mathrm{a}$ & 100 \\
HSND23 & $0.2 \mathrm{M}$ & 100 & 100 & 100 & $83( \pm 0.8) \mathrm{c}$ & 100 & $81( \pm 1.8) \mathrm{b}$ & 100 \\
HSWS04 & $0.2 \mathrm{M}$ & 100 & 100 & 100 & $84( \pm 1.4) \mathrm{bc}$ & 100 & $78( \pm 3.2) \mathrm{c}$ & 100 \\
\hline
\end{tabular}

${ }^{x}$ Growth was evaluated after 5 weeks incubation at $23^{\circ} \mathrm{C}$ and is represented as percent inhibition relative to growth on unamended V8 agar. Data were pooled from repeated experiments.

y Treatments followed by the same letter (in a column) are not significantly different from each other at $P<0.05$, according to Fisher's LSD.

${ }^{\mathrm{z}}( \pm \mathrm{SD})=$ Standard deviation. Means not followed by $( \pm$ SD) had identical values for all replicates, i.e., $\mathrm{SD}=0.0$. 
sodium and potassium bicarbonate exhibited only fungistatic effects, as cultures treated with these salts grew when transferred to fresh V8 agar plates. Because results of the repeated experiments did not differ in the homogeneity of variances, data were pooled for statistical analyses.

Radial growth of all isolates of $H$. solani was inhibited above $\mathrm{pH} 10$ and below $\mathrm{pH} 5$ relative to unamended $\mathrm{V} 8$ agar $(\mathrm{pH} 6.3)$. Growth of $H$. solani at $\mathrm{pH}$ values between 6.0 and 9.5 was not affected. Addition of salts $(0.2 \mathrm{M})$ to $\mathrm{V} 8$ agar or distilled water resulted in $\mathrm{pH}$ values between 6.4 and 11.3 , whereby only addition of sodium and potassium carbonate resulted in a $\mathrm{pH} \geq 10$. Because results of repeated experiments did not differ, data were pooled from both experiments. The relationship between radial growth and $\mathrm{pH}$ of the medium was evaluated with regression analysis fitting a quadratic model $(148.86+40.5 \mathrm{pH}-2.87$ $\left.\mathrm{pH}\left[R^{2}=0.82, P=0.0001\right]\right)$.

Postharvest treatment of inoculated tubers. Tubers treated with $0.2 \mathrm{M}$ solutions of the test compounds did not develop any lesions (or only one single small lesion on one tuber per treatment) during 6 weeks of incubation, whereas water-treated tubers developed lesions on $48 \%$ of the tuber surface (Fig. 1A). Sporulation on tubers treated with any of the salts was significantly lower $(P<0.05)$ than on tubers treated with water (Fig. 1B). The test compounds did not differ significantly $(P<$ $0.05)$ from one another in their effects on sporulation. This experiment was performed three times. Because data did not differ among experiments, results from repeated experiments were pooled before statistical analyses.

Postharvest treatment of field-grown tubers. After 15 weeks of incubation, the area of the tuber surface with silver scurf lesions was significantly $(P<0.05)$ reduced on the salt-treated tubers compared with the water-treated tubers (Fig. 2A). However, lesion development on tubers did not differ significantly among salt treatments. Sporulation studies revealed similar results. Tubers treated with the test compounds produced significantly $(P<0.05)$ fewer spores than did tubers treated with water (Fig. 2B), but salt treatments did not differ significantly $(P<0.05)$ from one another .

\section{DISCUSSION}

This study demonstrates that several organic and inorganic salts can inhibit growth of $H$. solani in vitro and reduce lesion development and sporulation of the pathogen on potato tubers. Radial growth inhibition of $H$. solani on salt-amended media was generally predictive of the ability of the salts to affect lesion development and sporulation on potato tubers. Sodium and potassium carbonate treatments were more effective than the respective bicarbonate salts, which exhibited only a fung- istatic effect in vitro at concentrations at which the other treatments were fungicidal. These results are consistent with other studies that demonstrated better disease control with carbonate salts $(27,38)$ than with bicarbonate salts. However, some differences among salt treatments were apparent in radial growth assays that were not observed in the in vivo studies. Isolates of $H$. solani varied in their response to salt treatments at low concentrations in vitro. This finding is consistent with other reports in which suppression of microbial strains varied within one species $(3,36)$.

\section{A}

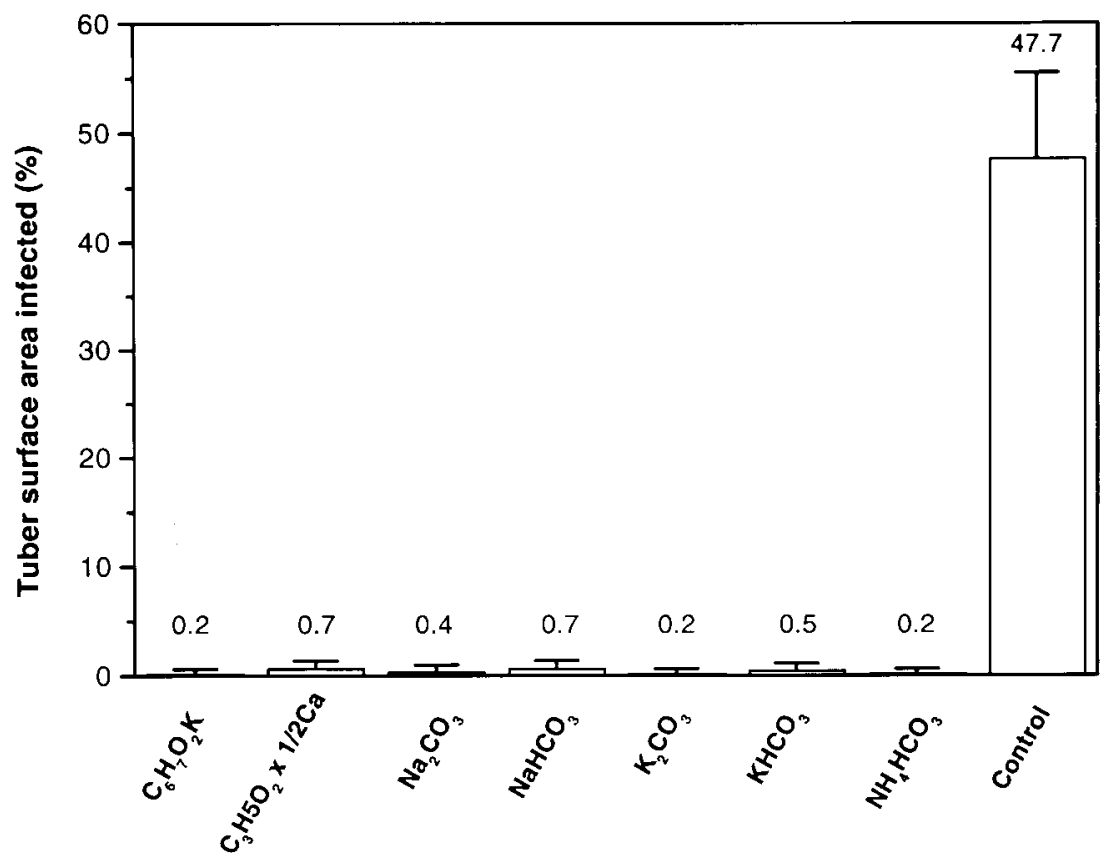

B

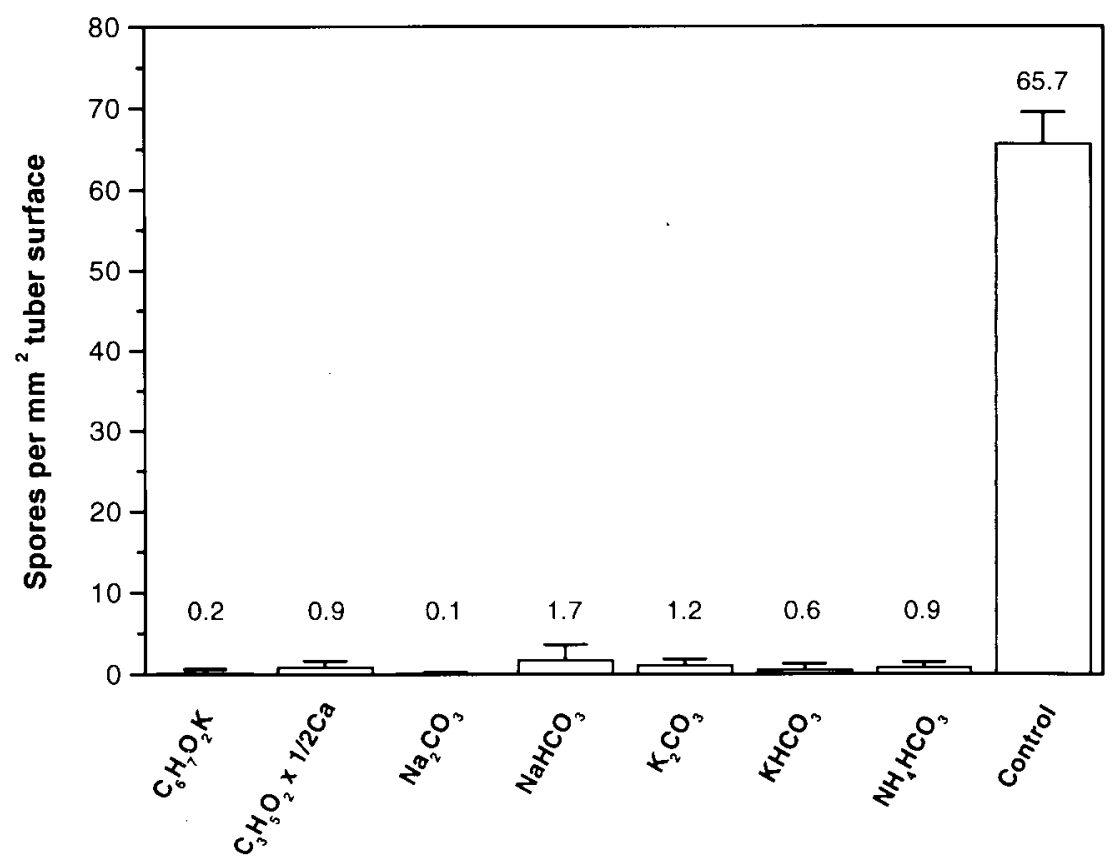

Fig. 1. Lesion development and sporulation on inoculated tubers. Greenhouse-grown tubers were inoculated with Helminthosporium solani spore suspensions and incubated for 5 days at $23^{\circ} \mathrm{C}$ in moist chambers. Tubers were then dipped into $0.2 \mathrm{M}$ solutions of the test compounds and incubated for another 6 weeks under the same conditions. (A) Tubers were evaluated for development of silver scurf lesions on the tuber surface (percent surface area with lesions). (B) Spore counts were performed on all tubers (spores per $\mathrm{mm}^{2}$ tuber surface). In (A) and (B), all salt treatments differed significantly $(P<0.05)$ from the water-treated control tubers; however, differences among salt treatments were not significant $(P<0.05)$. Graphs are shown with standard error bars. Data were pooled from repeated experiments. 
Organic and inorganic salts were effective in inhibiting growth and sporulation of $H$. solani and the development of silver scurf, as has been shown for several other host-pathogen systems. Ziv and Zitter (38) showed inhibition of fungal pathogens of cucurbits by application of bicarbonate salts. Sodium bicarbonate is effective against storage pathogens of citrus fruits
(15) as well as powdery mildew and black spot of roses (16). Carbonate and bicarbonate salts are fungicidal to Sclerotium rolfsii Sacc. (28). Inorganic salts also are successfully applied against a variety of mycotoxigenic fungi on animal feed, such as corn $(1,26)$ or cereals $(25)$.

In our study, salt treatments did not differ significantly $(P<0.05)$ in their effects

A

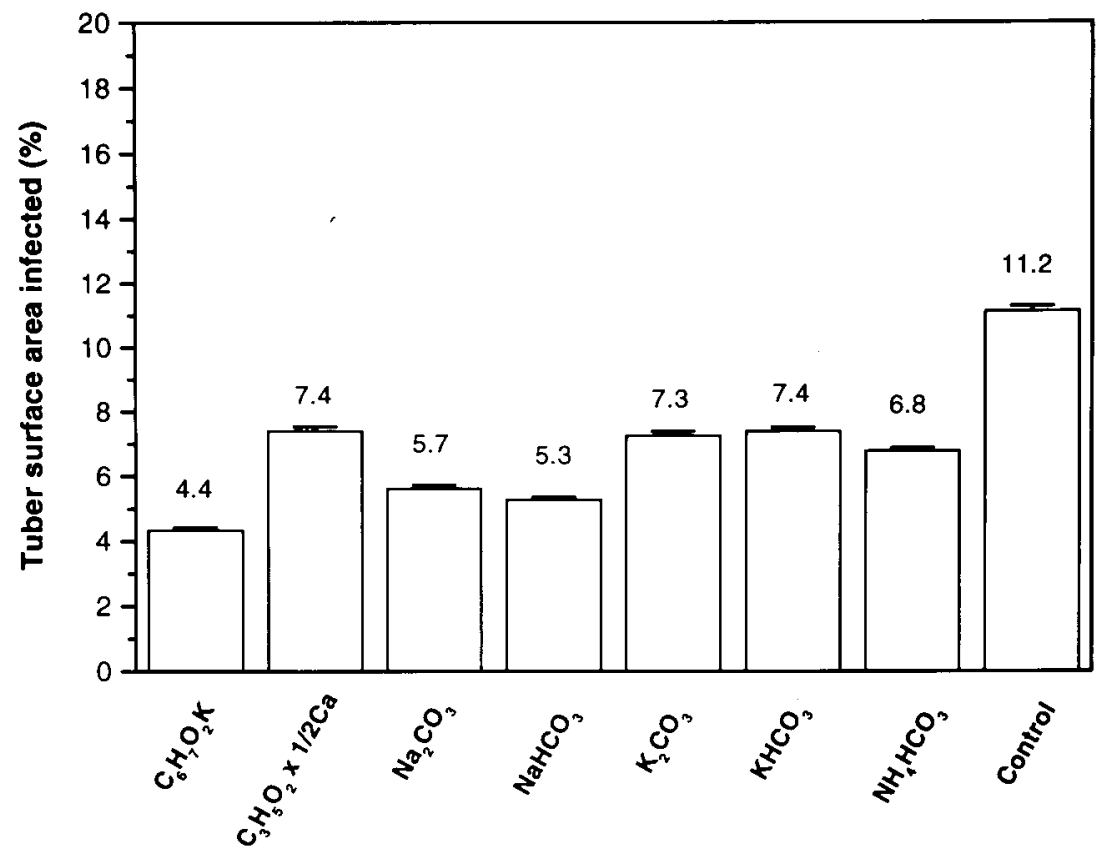

B

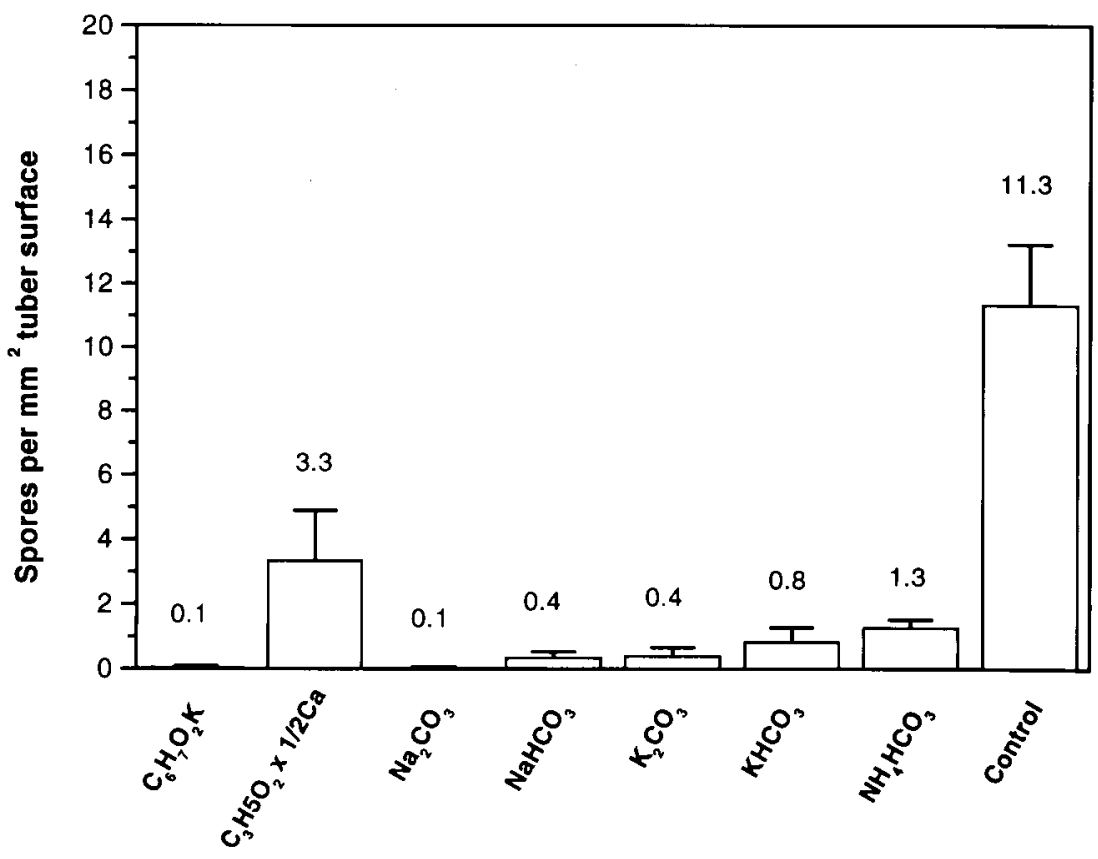

Fig. 2. Lesion development and sporulation on field-grown tubers that were naturally infected with Helminthosporium solani. Tubers were dipped into $0.2 \mathrm{M}$ solutions of the test compounds or water (80 tubers per treatment) and incubated for 15 weeks at $10^{\circ} \mathrm{C}$. (A) Tubers were evaluated for development of silver scurf lesions on the tuber surface. (B) Ten tubers of each treatment were incubated for an additional 3 weeks in a moist chamber at $23^{\circ} \mathrm{C}$, then spore counts were performed. In (A) and (B), all salt treatments differed significantly $(P<0.05)$ from the water-treated control tubers; however, differences among treatments were not significant. Graphs are shown with standard error bars.

on silver scurf control and pathogen sporulation, however, potassium sorbate always ranked first in efficacy. Sorbic acid and its salt derivatives are the most widely used antimicrobial agents for food preservation worldwide; they are also used as preservatives in animal feed, pharmaceuticals, and cosmetics $(34,35)$. The most commonly applied salt of sorbic acid, potassium sorbate, is reported to completely suppress growth of the banana pathogen Colletotrichum musae (Berk. \& M. A. Curtis) Arx in vitro (2). Sorbic acid inhibits growth of 15 different fungi isolated from "Pastilla" papers, a wheat-based dough (32).

Propionic acid and propionate are used as preserving additives in milled corn (11) and have been tested for the suppression of mycotoxins and storage molds $(11,30)$. Sebti and Tantaoui-Elaraki (32) reported that calcium propionate is less effective against fungal pathogens than is potassium sorbate. The present study supports these results, since calcium propionate was fungicidal only at concentrations $\geq 0.2 \mathrm{M}$ in vitro, whereas potassium sorbate was fungicidal at concentrations as low as $0.05 \mathrm{M}$ (data not shown). When applied to fieldgrown tubers, potassium sorbate treatment suppressed lesion and spore development on the tuber surface more efficiently than calcium propionate treatment.

Postharvest applications of salts were effective in reducing pathogen sporulation on both inoculated and naturally infected tubers. Similarly, all of these treatments reduced disease severity relative to the control on both types of tubers. However, disease severity was greater on naturally infected tubers for all of the treatments. The likely explanation for this difference is that lesion development was advanced in field-grown tubers, since infection can occur very early in the growing season $(10,23)$. In fact, some lesions were present on field-grown tubers at the time of treatment (data not shown). In contrast, $H$. solani inoculated tubers were incubated for five days to allow the pathogen to infect tubers before treatments were applied and lesions had not yet developed at the time that tubers were treated with salts.

In this study, $\mathrm{pH}$ was ruled out as a mechanism for suppression of $H$. solani by the salt treatments. This result is consistent with other reports and alternative modes of action have been proposed. The anions $\left(\mathrm{HCO}_{3}\right)^{-}$or $\left(\mathrm{CO}_{3}\right)^{2-}$ are primarily responsible for pathogen suppression by inorganic salts, and the cation plays only a minor role in the interaction $(7,28)$. Ammonium bicarbonate represents an exception, since it is known that ammonia as well as the anion contribute a great deal to the toxicity of ammonium bicarbonate under alkaline conditions. Bicarbonates may alter membrane permeability, uncouple oxidative phosphorylation reactions, and stimulate 
mitochondrial ATPases (9). Homma and Arimoto (14) reported the collapse of hyphal cell walls and a shrinkage of conidia after exposure to potassium bicarbonate.

Propionate or its metabolic intermediates are suggested to act via interference with the pyruvate dehydrogenation (21). Inhibition of microorganisms by sorbic acid and its salts may be caused by alteration of cell membranes and cell transport functions, inhibition of enzymes involved in the glycolytic pathway or tricarboxylic acid cycle, by inhibition of RNA, DNA, and protein synthesis, and by uncoupling of the oxidative phosphorylation in mitochondria $(34,35)$. The depletion of ATP was reported in conidia of various molds after exposure to sorbic acid (6). Sorbic acid can be metabolized by certain microbes as a carbon source. The very low levels of mammalian toxicity of potassium sorbate (LD 50 in rat: $4-7 \mathrm{~g} / \mathrm{kg}$ body weight, equals $500 \mathrm{~g}$ for an adult human) and its wide application as a food preservative (34) would make it an excellent candidate for postharvest treatment of potato tubers.

This study demonstrates that carbonate and bicarbonate salts, potassium sorbate, and calcium propionate may have potential as environmentally compatible, nontoxic postharvest fungicides for silver scurf control. However, several additional factors should be addressed to optimize disease control and integrate these postharvest treatments into the potato production system. Further studies will be conducted to test whether soil adhering to potato tubers after harvest will affect the efficacy of the salts. Slightly increased salt concentrations may be necessary to overcome this problem. However, since organic salts perform better at an acidic $\mathrm{pH}(27,28,34)$, addition of an acidifying compound to the organic salts could improve the efficacy of potassium sorbate and calcium propionate, therefore allowing the use of reduced rates of these compounds. Furthermore, the efficacy of salt treatments might be increased by addition of surfactants or coating polymers to the treatments, as has been shown in other studies $(16,25,38)$. It is also necessary to test the effect of these salts on wound healing, since this process is critical to control of other postharvest diseases of potato, including Fusarium dry rot and bacterial soft rot.

\section{ACKNOWLEDGMENTS}

This research was supported in part by the USDA/ARS Potato Research Grants Program, Agreement No. 58-5442-6-126.

\section{LITERATURE CITED}

1. Abdelhamid, A. M., Sadik, E. A., and Fayzalla, E. A. 1985. Preserving power of some additives against fungal invasion and mycotoxin production in stored-crushed-corn containing different levels of moisture. Acta Phytopathol. Acad. Sci. Hung. 20:309-320.
2. Al Zaemey, A. B., Magan, N., and Thompson, A. K. 1993. Studies on the effect of fruitcoating polymers and organic acids on growth of Colletotrichum musae in vitro and on postharvest control of anthracnose of bananas. Mycol. Res. 97:1463-1468.

3. Blocher, J. C., and Busta, F. F. 1985. Multiple modes of action of spore germination and outgrowth by reduced $\mathrm{pH}$ and sorbate. J. Appl. Bacteriol. 95:469-478.

4. Buazzi, M. M., and Marth, E. H. 1991. Mechanisms of the inhibition of Listeria monocytogenes by potassium sorbate. Food Microbiol. 8:249-256.

5. Burke, O. D. 1938. The silver scurf of potatoes. Cornell Univ. Agric. Exp. Stn. Bull. 692.

6. Cheng, L., and Piper, P. W. 1994. Weak acid preservatives block the heat shock response and heat-shock-element-directed lac Z expression of low $\mathrm{pH}$ Saccharomyces cerevisiae cultures, an inhibitory action partially relieved by respiratory deficiency. Microbiology 140:1085-1096.

7. Corral, L. G., Post, L. S., and Montville, T. J. 1988. Antimicrobial activity of sodium bicarbonate. J. Food Sci. 53:981-982.

8. DePasquale, D. A., El-Nabarawy, A., Rosen, J. D., and Montville, T. J. 1990. Ammonium bicarbonate inhibition of mycotoxigenic fungi and spoilage yeasts. J. Food Prot. 53:324-328.

9. DePasquale, D. A., and Montville, T. J. 1990. Mechanism by which ammonium bicarbonate and ammonium sulfate inhibit mycotoxigenic fungi. Appl. Environ. Microbiol. 56:37113717.

10. Firman, D. M., and Allen, E. J. 1995. Transmission of Helminthosporium solani from potato seed tubers and effects of soil conditions, seed inoculum and seed physiology on silver scurf disease. J. Agric. Sci. 124:219234.

11. Furtner, K. 1973. Konservierung von Feuchtgetreide mit Propionsäure und ihr Einfluss auf den ernährungsphysiologischen Wert des Futters. Veröffentlichungen anläßich des 60 . Geburtstages von Hochschulprofessor Dr. F. Turek. Wien, Univ. Boku. 5:19-30.

12. Heiny, D. H., and McIntyre, G. A. 1983. Helminthosporium solani Dur. \& Mont. development on potato periderm. Am. Potato J. 60:773-789.

13. Hide, G. A., Hall, S. M., and Borer, K. J. 1988. Resistance to thiabendazole in isolates of Helminthosporium solani, the cause of silver scurf of potatoes. Plant Pathol. 37:229240.

14. Homma, Y., and Arimoto, Y. 1990. Mechanisms of plant disease control by potassium bicarbonate. (Abstr.) Int. Congr. Pestic. Chem. 17th. 2:94.

15. Homma, Y., Arimoto, Y., and Misato, T. 1981. The control of citrus storage disease by sodium bicarbonate formulation. Proc. Int. Soc. Citric. 2:823-825.

16. Horst, R. K., Kawamoto, S. O., and Porter, L. L. 1992. Effect of sodium bicarbonate and oils on the control of powdery mildew and black spot of roses. Plant Dis. 76:247-251.

17. Jellis, G. J., and Taylor, G. S. 1974. The relative importance of silver scurf and black dot: two disfiguring diseases of potato tubers. ADAS Q. Rev. 14:53-61.

18. Jellis, G. J., and Taylor, G. S. 1977. The development of silver scurf (Helminthosporium solani) disease of potato. Ann. Appl. Biol. 86:19-28.

19. Kawchuck, L. M., Holley, J. D., Lynch, D. R., and Clear, R. M. 1994. Resistance to thiabendazole and thiophanate-methyl in Canadian isolates of Fusarium sambucinum and Helminthosporium solani. Am. Potato J.
71:185-192.

20. Lennard, J. H. 1980. Factors affecting the development of silver scurf (Helminthosporium solani) on potato tubers. Plant $\mathrm{Pa}-$ thol. 29:87-92.

21. Maruyama, K., and Kitamura, H. J. 1985. Mechanisms of growth inhibition by propionate and restoration of the growth by sodium bicarbonate or acetate in Rhodopseudomonas sphaeroides. J. Biochem. 98:819-824.

22. Merida, C. L., and Loria, R. 1990. First report of resistance of Helminthosporium solani to thiabendazole in the United States. Plant Dis. 74:614.

23. Merida, C. L., and Loria, R. 1994. Survival of Helminthosporium solani in soil and in vitro colonization of senescent plant tissue. Am. Potato J. 71:591-598.

24. Merida, C. L., Loria, R., and Halseth, D. E., 1994. Effects of potato cultivar and time of harvest on the severity of silver scurf. Plant Dis. 78:146-149.

25. Montville, T. J., and Goldstein, P. K. 1989. Sodium bicarbonate inhibition of aflatoxigenesis in corn. J. Food Prot. 52:45-48.

26. Montville, T. J., and Shih, P. L. 1991. Inhibition of mycotoxigenic fungi in corn by ammonium and sodium bicarbonate. J. Food Prot. 54:295-297.

27. Punja, Z. K., and Gaye, M. M. 1993. Influence of postharvest handling practices and dip treatments on development of black root rot on fresh market carrots. Plant Dis. 77:989995.

28. Punja, Z. K., and Grogan, R. G. 1982. Effects of inorganic salts, carbonate-bicarbonate anions, ammonia and the modifying influence of $\mathrm{pH}$ on sclerotial germination of Sclerotium rolfsii. Phytopathology 72:635-639.

29. Rodriguez, D. A., Secor, G. A., Gudmestad, N. C., and Francl, L. J. 1996. Sporulation of Helminthosporium solani and infection of potato tubers in seed and commercial storages. Plant Dis. 80:1063-1070.

30. Rusul, G., El-Gazzar, F. E., and Marth, E. H 1987. Growth and aflatoxin production by Aspergillus parasiticus NRRL 2999 in the presence of propionic acid and at different initial $\mathrm{pH}$ values. J. Food Prot. 50:909-914.

31. Rusul, G., and Marth, E. H. 1987. Growth and aflatoxin production by Aspergillus parasiticus NRRL 2999 in the presence of potassium benzoate or potassium sorbate and at different initial $\mathrm{pH}$ values. J. Food Prot. 50:820-825.

32. Sebti, F., and Tantaoui-Elaraki, A. 1994. In vitro inhibition of fungi isolated from 'Pastilla' papers by organic acids and cinnamon. Lebensm. Wiss. Technol. 27:370-374.

33. Snedecor, G. W., and Cochran, W. G. 1989 Statistical Methods, 8th ed. Iowa State University Press, Ames, IA. 503 pp.

34. Sofos, J. N. 1992. Sorbic acid, mode of action. Pages 43-52 in: Encyclopedia of Microbiology, Vol. 4. J. Lederberg, ed. Academic Press, San Diego, CA.

35. Sofos, J. N., Pierson, M. D., Blocher, J. C., and Busta, F. F. 1986. Mode of action of sorbic acid on bacterial cells and spores. Int. J. Food Microbiol. 3:1-17.

36. Stead, D. 1995. The effect of hydroxycinnamic acids and potassium sorbate on the growth of 11 strains of spoilage yeasts. J. Appl. Bacteriol. 7:82-87.

37. Ziv, O., and Frederiksen, R. A. 1987. The effect of film-forming antitranspirants on leaf rust and powdery mildew incidence on wheat. Plant Pathol. 36:242-245.

38. Ziv, O., and Zitter, T. A. 1992. Effects of bicarbonates and film-forming polymers on cucurbit foliar diseases. Plant Dis. 76:513517. 